"The issue of this journal is the realisation of a hope of many years," wrote the Director General of the time in the first issue of the Journal of the Royal Army Medical Corps in July 1903. This was somewhat of an understatement as it was in fact the result of 39 years of effort against some powerful opposition, the first meeting to try and initiate the publication of a Corps Journal having taken place as early as 1864 . We are now 93 years on with an unbroken record of the work of the Corps in war and peace, from South Africa at the turn of the century to Bosnia today. Our centenary is in sight.

The implementation of DCS 15(1) has reduced the number of hospital based medical officers amongst whom those in higher professional training had been frequent contributors of articles. There has consequently been a significant and worrying drop in submissions. I would therefore make a plea to medical officers of all three services, regular and reserve, to submit articles to what is a 'bona fide' medical journal listed in Index Medicus.

If anyone doubts the value of such a journal then I would suggest a browse through past copies. It has been said that in each war we re-learn the lessons of the last, if this remains so today then it is a sad reflection of our medical services. However, if we fail to keep easily accessible academic records, then it is inevitable.

GO HOPKINS

\section{REFERENCES}

1. MacMillan AHM. Editorial - Defence Costs Study 15. J R Army Med Corps 1996; 142: 3-8.

\title{
ACADEMIC ACHIEVEMENTS
}

FRCP(Lond)

$\operatorname{FRCS}($ Eng)

FRCS(Ed)

MRCGP
Lieutenant Colonel BM Bhatt, RAMC

Major PF Hill, RAMC

Major G Banfield, RAMC

Major NJ Crabbe, RAMC

Major L Scott, RAMC

Major MJS Weir, RAMC

Captain MJ Blackwell, RAMC

Captain AJR Bushby, RAMC

Captain AF Standring, RAMC

Captain MC Walker, RAMC 